\title{
Clinical Reasoning: An 81-year-old woman with confusion, weakness, and left-sided hemineglect
}

Stefan Torelli, BS, Abhishek Lenka, MD, PhD, Fahad Khan, DO, and Faria Amjad, MD

Neurolog ${ }^{\circledR}$ 2020;95:e3060-e3064. doi:10.1212/WNL.0000000000010472
Correspondence

Dr. Lenka

gemsabhishek@gmail.com

\section{Section 1}

An 81-year-old right-handed woman presented to the emergency department (ED) with confusion, generalized weakness, and difficulty ambulating. In addition to several cardiovascular comorbidities (hypertension, hyperlipidemia, peripheral arterial disease, coronary artery disease, chronic kidney disease, and renal artery stenosis), her medical history was significant for stage IV carcinoma of the urinary bladder. She had been in her usual state of health until 1 week prior to her presentation when she began experiencing generalized weakness in her legs, requiring more frequent use of a walker as well as intermittent headaches and increasing forgetfulness. Two to 3 days prior to presentation, her husband noted that she was increasingly getting confused. On the day of presentation, she woke up disoriented and was too weak to get out of bed, prompting her husband to bring her to the ED. In the ED, she was afebrile, hypertensive $(180 / 90 \mathrm{~mm} \mathrm{Hg}$ ), and tachycardic (heart rate $120-130 / \mathrm{min}$ ). On mental status examination, she was intermittently oriented to time and place and unable to follow complex instructions. Her score on the Montreal Cognitive Assessment (MoCA) was 9/30. Other pertinent examination findings included left facial weakness (lower face) and left upper and lower extremity weakness (3/5). Sensory examination revealed left-sided hemineglect. The patient was unable to ambulate as she could not stand without assistance.

The patient had been diagnosed with stage IV metastatic transitional cell carcinoma of the urinary bladder 2 years before the current admission and had gone into remission following therapy with gemcitabine and cisplatin. Eight months prior, she began immunotherapy with pembrolizumab infusions every 3 weeks after a follow-up PET scan showed nodal metastases, indicative of probable disease progression. Her most recent PET scan ( 2 weeks before the current admission) revealed interval improvement of the nodal metastases with pembrolizumab and absence of any new lesions. Her husband reported that she had experienced pembrolizumab-related adverse effects such as rash and colitis several months prior which resolved with steroids. She had otherwise been tolerating the immunotherapy well and had received her last infusion 2 weeks prior to presentation.

\section{Questions for consideration:}

1. What is the differential diagnosis given the presentation and history?

2. What diagnostic tests would you perform?

\section{GO TO SECTION 2}




\section{Section 2}

This presentation of altered mental status with acute/ subacute-onset focal neurologic deficits certainly indicates a CNS pathology. Stroke remains at the forefront of the differential diagnoses, primarily because of the fast onset of the neurologic deficits in the background of multiple cardiovascular risk factors, including the history of myocardial infarction. However, it is important to keep the differentials wide and resist the temptation to anchor only towards stroke. Infections of the CNS (meningitis or encephalitis) remain an important differential here because of the acute to subacute onset of confusion and neurologic deficits. The patient's history of metastatic cancer makes paraneoplastic disease process and new metastasis to the meninges or brain parenchyma a reasonable differential diagnosis. Although not supported by the rapid onset of the symptoms, altered mental status and gait impairment in an elderly patient prompts the inclusion of normal-pressure hydrocephalus (NPH) into the list of differentials. Given the history of transitional cell carcinoma of the urinary bladder, cancer-associated Wernicke-Korsakoff syndrome is reasonable to consider as it may present with ataxia, altered mental status, and weakness. ${ }^{1}$ Finally, as checkpoint inhibitors are rarely associated with autoimmune neurologic side effects including encephalitis, aseptic meningitis, and hypophysitis, ${ }^{2}$ pembrolizumabassociated adverse effects are important to consider.

Among the differential diagnoses mentioned above, it is essential to evaluate for stroke first. Investigations for stroke include noncontrast CT of the head, CT angiogram, CT perfusion, and MRI of the brain (noncontrast). These investigations did not reveal any evidence of acute stroke. MRI brain (without contrast), however, revealed ventriculomegaly out of proportion to the cortical atrophy.

Because of the ventriculomegaly, a high-volume CSF tap was essential in this case as the patient also had 2 cardinal symptoms of NPH, i.e., cognitive dysfunction and gait impairment. Opening and closing pressure, while not obtained on this patient, would be useful to measure. Moreover, CSF analysis (routine cell counts, cytologic, biochemical, and microbiological examinations) is necessary to investigate 2 differential diagnoses, i.e., CNS infection and metastasis to the meninges. MRI of the brain was repeated (with contrast) as it was essential for the remaining differential diagnoses, i.e., CNS infections, metastasis, and immunotherapy adverse effects such as aseptic meningitis or hypophysitis. In addition, the patient's lower extremity weakness and ataxic gait warranted MRI of the whole spine. Considering the history of cancer, serum paraneoplastic panel is of paramount importance. Although we did not check thiamine level to evaluate for Wernicke encephalopathy (as onset was rapid), this should be regarded as one of the important differentials in the background of advanced cancers. In addition to these targeted investigations, complete blood count, comprehensive metabolic panel, vita$\min B_{12}$, folate, and workup for syphilis and HIV are crucial.

A high-volume lumbar puncture $(24 \mathrm{~mL})$ did not result in substantial improvement in gait or cognition (MoCA remained unchanged). MRI brain (with contrast) was motion-degraded, which made visualization on any contrast enhancement difficult. However, there was leptomeningeal enhancement in the cauda equina and conus (figure, A and B). CSF analysis was significant for lymphocytic pleocytosis $\left(18 / \mathrm{mm}^{3}\right)$, low glucose $(<1 \mathrm{mg} / \mathrm{dL})$, and elevated protein

Figure MRI abnormalities in the lumbar segment of the spinal cord
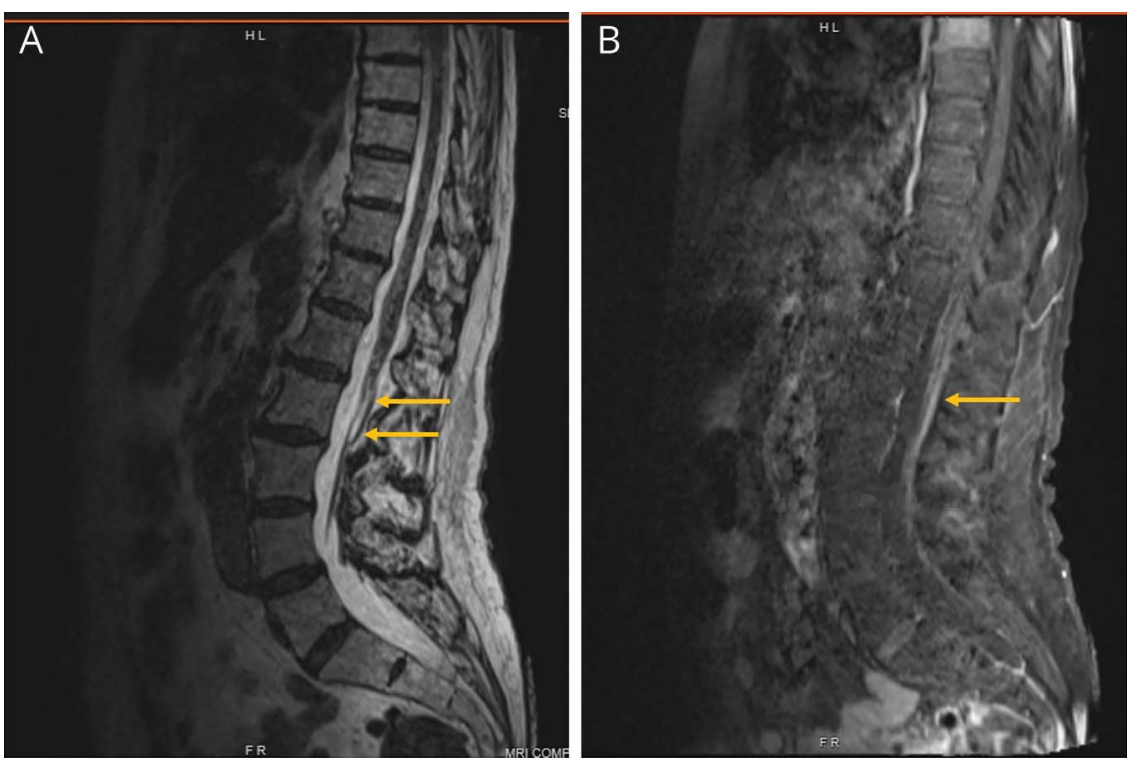

(A) Sagittal T2 sequence of the lumbar spine demonstrating hyperintense signal changes in the L1-L2 level. (B) Sagittal T1 (postcontrast) sequence of the lumbar spine demonstrating contrast enhancement around the L1-L2 level. 
Table Differential diagnoses, pertinent investigations, and their results

\begin{tabular}{|c|c|c|c|}
\hline Categories & $\begin{array}{l}\text { Differential } \\
\text { diagnoses }\end{array}$ & Investigation & Pertinent results \\
\hline Vascular & Stroke & $\begin{array}{l}\text { Noncontrast CT of head, CT angiogram of } \\
\text { head and neck, CT perfusion, MRI (without } \\
\text { contrast) }\end{array}$ & $\begin{array}{l}\text { No evidence for acute stroke } \\
\text { Ventriculomegaly out of proportion to cortical } \\
\text { atrophy on MRI }\end{array}$ \\
\hline Neurodegenerative & $\begin{array}{l}\text { Normal-pressure } \\
\text { hydrocephalus }\end{array}$ & $\begin{array}{l}\text { High-volume CSF tap with opening and } \\
\text { closing pressures }\end{array}$ & $\begin{array}{l}\text { No improvement in gait or MoCA score after high- } \\
\text { volume CSF tap; opening/closing pressures not } \\
\text { measured }\end{array}$ \\
\hline Metabolic & $\begin{array}{l}\text { Wernicke } \\
\text { encephalopathy, } \\
\mathrm{B}_{12} \text { deficiency }\end{array}$ & Thiamine level, $B_{12}$ level & $\begin{array}{l}\text { Vitamin B12-within normal limits (thiamine was } \\
\text { measured for this patient) }\end{array}$ \\
\hline Infectious & $\begin{array}{l}\text { Meningitis } \\
\text { Encephalitis }\end{array}$ & $\begin{array}{l}\text { CSF analysis; CSF infectious panel (HSV, VZV, } \\
\text { West Nile, bacterial culture); T-spot; VDRL; HIV }\end{array}$ & $\begin{array}{l}\text { Lymphocytic pleocytosis }\left(18 / \mathrm{mm}^{3}\right) \text {, low glucose } \\
(<1 \mathrm{mg} / \mathrm{dL}) \text {, elevated protein }(114 \mathrm{mg} / \mathrm{dL})\end{array}$ \\
\hline $\begin{array}{l}\text { Toxic/treatment } \\
\text { related }\end{array}$ & $\begin{array}{l}\text { Hypophysitis } \\
\text { Immunotherapy- } \\
\text { associated } \\
\text { encephalopathy }\end{array}$ & $\begin{array}{l}\text { MRI brain with contrast; TSH (hypophysitis) } \\
\text { Urine toxicology }\end{array}$ & $\begin{array}{l}\text { No signal changes in pituitary } \\
\text { Normal TSH and urine toxicology }\end{array}$ \\
\hline Cancer-related & $\begin{array}{l}\text { Metastatic and } \\
\text { paraneoplastic }\end{array}$ & $\begin{array}{l}\text { MRI brain with contrast, MRI spine with } \\
\text { contrast, CSF cytology }\end{array}$ & $\begin{array}{l}\text { Leptomeningeal enhancement of cauda equina and } \\
\text { conus medullaris } \\
\text { Scattered malignant cells on cytology } \\
\text { Paraneoplastic panel: negative }\end{array}$ \\
\hline
\end{tabular}

Abbreviations: HSV = herpes simplex virus; MoCA = Montreal Cognitive Assessment; $T S H=$ thyroid-stimulating hormone; VDRL = Venereal Disease Research Laboratory test; VZV = varicella-zoster virus.

$(114 \mathrm{mg} / \mathrm{dL}$ ). Infectious workup (herpes simplex virus, Venereal Disease Research Laboratory, bacterial culture) of CSF was unremarkable. Subsequently, cytology examination of CSF revealed scattered malignant cells with enlarged nuclei and a high nucleocytoplasmic ratio in a background of reactive lymphocytes, consistent with metastatic urothelial carcinoma. Serum paraneoplastic panel was negative, and the rest of the laboratory investigations mentioned above were within normal limits. The table summarizes the differential diagnoses for this case, pertinent investigations, and their results.

\section{Questions for consideration:}

1. What is the most likely diagnosis given these findings?

2. What is the most significant finding that supports this diagnosis? 


\section{Section 3}

CSF investigation was the key in this case. CSF glucose was very low (hypoglycorrhachia) in the background of elevated protein and lymphocytic pleocytosis. The major differential diagnoses for this CSF profile are tubercular meningitis (TBM) and carcinomatous meningitis. The patient did not have any signs or symptoms of TBM. She had no cough, fever, night sweats, neck stiffness, or photophobia. Importantly, T-spot was negative, and the $\mathrm{X}$-ray of the chest was unremarkable, making a diagnosis of tuberculosis unlikely. Hence, the suspicion for carcinomatous meningitis became stronger. Later, positive cytology examination tilted the diagnosis in favor of carcinomatous meningitis. Enhancement of the conus medullaris and cauda equina further reinforced this diagnosis.

Carcinomatous meningitis is rare and typically occurs late in the course of the disease. It is most often a result of hematogenous spread of tumor cells to the subarachnoid space and into the CSF. Diagnosis is usually based on imaging and CSF analysis. ${ }^{3}$ The condition is most commonly associated with primary tumors of the breast or lung, as well as with melanoma. ${ }^{3,4}$ Carcinomatous meningitis secondary to bladder cancer is rare, and to date, only 33 case reports are available in the literature. ${ }^{5}$ The majority of these cases involved transitional cell carcinoma, as observed in our patient.

\section{Questions for consideration:}

1. What is the typical presentation and diagnostic workup for carcinomatous meningitis?

2. What are the treatment options and prognosis?

\section{Discussion}

Carcinomatous meningitis refers to the metastatic infiltration of the leptomeninges by malignant cells. The primary tumors are usually from lungs, breasts, and melanoma. Carcinomatous meningitis usually results in multifocal neurologic signs and symptoms. ${ }^{3,4}$ The spectrum and severity of the symptoms depend on the extent of dissemination of the malignant cells in the CNS. Headache, nausea, vomiting, altered mental status, and ataxia are some of the commonly reported symptoms. ${ }^{3,4}$ Diplopia, visual loss, hearing loss, and facial weakness are frequently reported symptoms of cranial nerve involvement. ${ }^{3-6}$ Spinal involvement may result in neck pain, back pain, paresthesia, weakness, and bladder and bowel dysfunction.

Multiaxial symptoms and signs in our patient (altered mental status, gait impairment, diffuse headache, nausea, weakness, and left facial droop) made the neuroanatomical localization challenging. In carcinomatous meningitis secondary to transitional cell carcinoma, the most common presenting symptoms reported are diffuse headache and mental status changes. ${ }^{7}$ In a review of 22 reported cases, 5 had cranial nerve involvement, and all but one of these cases had cranial nerve
VII involvement. ${ }^{7}$ There have been no reports of carcinomatous meningitis-associated sensory hemineglect that we are aware of, but sensory disturbance is not uncommon. ${ }^{8}$

The MRI and CSF examination of our patient was markedly abnormal, and this has been reported in a few cases of transitional cell carcinoma-associated carcinomatous meningitis. ${ }^{6}$ As this disease process can involve the entire neuroaxis, imaging of the brain and spinal cord is recommended as part of the diagnostic workup. However, findings on MRI are nonspecific and may not be diagnostic on their own. ${ }^{3,5}$ Hence, CSF analysis is often key to the diagnosis. Repeated CSF sampling may be necessary; approximately $50 \%$ of patients have positive cytology on initial lumbar puncture whereas $75 \%$ are positive on the second, with yield increasing by $2 \%$ on each sample taken after that. ${ }^{3}$ Analysis of our patient's CSF revealed lymphocytic pleocytosis, hypoglycorrhachia, elevated protein, and positive cytology, which are the classical CSF findings of carcinomatous meningitis.

Treatment options for carcinomatous meningitis typically include chemotherapy (systemic or intrathecal) and radiotherapy. The commonly used chemotherapy agents include methotrexate, cytarabine, and thiotepa. ${ }^{4}$ Radiotherapy typically involves whole brain radiotherapy or craniospinal irradiation with targeted techniques such as intensity-modulated radiotherapy or proton therapy. ${ }^{9}$ While the median survival of untreated patients with carcinomatous meningitis is 1 month, treatment with the aforementioned modalities improves the median survival to approximately 3 months. ${ }^{7}$ However, prognosis may vary based on the underlying cancer. High Karnofsky Performance Status at diagnosis is significantly associated with better prognosis as well as ability to tolerate and respond to treatment. ${ }^{10}$ In patients with poor Performance Status or those who do not desire further intervention, hospice care is an important option to offer. Given her poor prognosis, our patient's family opted to undergo hospice care. She died at home 3 weeks following the initial presentation.

This case represents an unusual and serious complication of transitional cell carcinoma. While few cases have been reported in the literature, the incidence of carcinomatous meningitis in general is predicted to increase along with improved cancer survival times. Therefore, carcinomatous meningitis should be under consideration in patients presenting with multifocal neurologic deficits, particularly in those with a history of cancer. As false negatives on both imaging and CSF analysis are not uncommon, diagnosis may be difficult and often relies on clinical suspicion.

\section{Study funding}

No targeted funding reported.

\section{Disclosure}

The authors report no disclosures relevant to the manuscript. Go to Neurology.org/N for full disclosures. 


\section{Appendix Authors}

\begin{tabular}{lll}
\hline Name & Institute & Contribution \\
\hline $\begin{array}{l}\text { Stefan } \\
\text { Torelli, BS }\end{array}$ & $\begin{array}{l}\text { Georgetown University } \\
\text { School of Medicine, } \\
\text { Washington, } \\
\text { DC }\end{array}$ & $\begin{array}{l}\text { Conception, organization, } \\
\text { writing the first draft }\end{array}$ \\
\hline $\begin{array}{l}\text { Abhishek } \\
\text { Lenka, MD, } \\
\text { PhD }\end{array}$ & $\begin{array}{l}\text { MedStar-Georgetown } \\
\text { Wniversity Hospital, }\end{array}$ & $\begin{array}{l}\text { Conception, organization, } \\
\text { data collection, analysis, } \\
\text { writing the final draft }\end{array}$ \\
\hline $\begin{array}{l}\text { Fahd Khan, } \\
\text { MD }\end{array}$ & $\begin{array}{l}\text { MedStar-Georgetown } \\
\text { University Hospital, } \\
\text { Washington, } \\
\text { DC }\end{array}$ & $\begin{array}{l}\text { Conception, organization, } \\
\text { data collection, analysis, } \\
\text { writing the first draft }\end{array}$ \\
\hline $\begin{array}{l}\text { Faria } \\
\text { Amjad, MD }\end{array}$ & $\begin{array}{l}\text { MedStar-Georgetown } \\
\text { University Hospital, } \\
\text { Washington, DC }\end{array}$ & $\begin{array}{l}\text { Conception, organization, } \\
\text { critical review of the 1st draft }\end{array}$ \\
\hline
\end{tabular}

\section{References}

1. Isenberg-Grzeda E, Rahane S, DeRosa AP, Ellis J, Nicolson SE. Wernicke-Korsakoff syndrome in patients with cancer: a systematic review. Lancet Oncol 2016;17:e142-e148.

2. Dalakas MC. Neurological complications of immune checkpoint inhibitors: what happens when you 'take the brakes off' the immune system. Ther Adv Neurol Disord 2018;11:1756286418799864.

3. Gleissner B, Chamberlain MC. Neoplastic meningitis. Lancet Neurol 2006;5:443-452.

4. Le Rhun E, Taillibert S, Chamberlain M. Carcinomatous meningitis: leptomeningeal metastases in solid tumors. Surg Neurol Int 2013;4:S265-S288.

5. Rigakos G, Liakou CI, Felipe N, Orkoulas-Razis D, Razis E. Clinical presentation, diagnosis, and radiological findings of neoplastic meningitis. Cancer Control 2017;24:9-21.

6. Umezawa Y, Shirotake S, Kaneko G, et al. Meningeal carcinomatosis from bladder cancer: a case report and review of the literature. Mol Clin Oncol 2019;10:506-510.

7. Bowen CD, Von Burton G, Bargen RC, et al. Carcinomatous meningitis secondary to transitional cell bladder cancer. South Med J 2010;103:809-812.

8. Balm M, Hammack J. Leptomeningeal carcinomatosis: presenting features and prognostic factors. Arch Neurol 1996;53:626-632.

9. El Shafie RA, Böhm K, Weber D, et al. Outcome and prognostic factors following palliative craniospinal irradiation for leptomeningeal carcinomatosis. Cancer Manag Res 2019;11:789-801.

10. Brower JV, Saha S, Rosenberg SA, Hullett CR, Ian Robins H. Management of leptomeningeal metastases: prognostic factors and associated outcomes. J Clin Neurosci 2016;27:137. 


\section{Neurology}

\section{Clinical Reasoning: An 81-year-old woman with confusion, weakness, and left-sided hemineglect}

Stefan Torelli, Abhishek Lenka, Fahad Khan, et al.

Neurology 2020;95;e3060-e3064 Published Online before print July 29, 2020

DOI 10.1212/WNL.0000000000010472

This information is current as of July 29, 2020

\section{Updated Information \&} Services

References

Subspecialty Collections

Permissions \& Licensing

Reprints including high resolution figures, can be found at: http://n.neurology.org/content/95/22/e3060.full

This article cites 10 articles, 0 of which you can access for free at: http://n.neurology.org/content/95/22/e3060.full\#ref-list-1

This article, along with others on similar topics, appears in the following collection(s):

All Clinical Neurology

http://n.neurology.org/cgi/collection/all_clinical_neurology All Oncology

http://n.neurology.org/cgi/collection/all_oncology

Clinical neurology history

http://n.neurology.org/cgi/collection/clinical_neurology_history Metastatic tumor

http://n.neurology.org/cgi/collection/metastatic_tumor

Information about reproducing this article in parts (figures,tables) or in its entirety can be found online at:

http://www.neurology.org/about/about_the_journal\#permissions

Information about ordering reprints can be found online:

http://n.neurology.org/subscribers/advertise

Neurology ${ }^{\circledR}$ is the official journal of the American Academy of Neurology. Published continuously since 1951 , it is now a weekly with 48 issues per year. Copyright (C) 2020 American Academy of Neurology. All rights reserved. Print ISSN: 0028-3878. Online ISSN: 1526-632X.

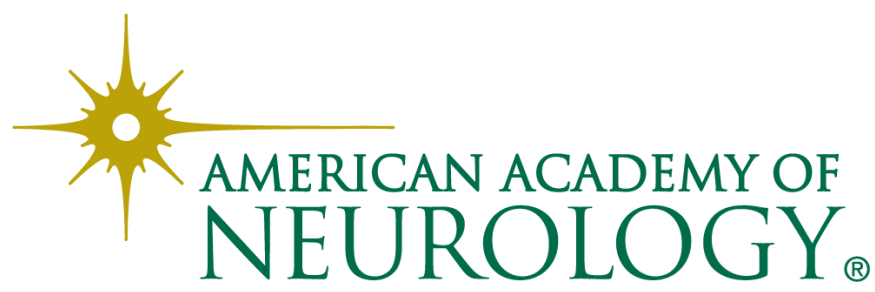

